\title{
ADVERSARIAL MODEL OF PRE-TRIAL INVESTIGATION: ILLUSIONS AND REALITY
}

\section{Shepitko V. Y.}

The article analyzes certain trends in the mechanism of the adversarial process at the pre-trial investigation stage. It attempts to determine legislative changes in the regulation of the pre-trial investigation as a stage in criminal proceedings. The article also focuses on the essence of the investigation activity, the order of its implementation, the investigator's functions and powers. At the same time any investigation has to ultimately aim at establishing the truth. The article determines the functional purposes of investigation (search) actions as well as secret investigation (search) actions and points out to certain problems and deficiencies in the course of their implementation. It dwells on the peculiarities of addressing special knowledge by various parties of the criminal proceedings (the state prosecution and the defense). The article concludes that at present the parties to the criminal trial proceedings do not have equal access to special knowledge. With this regard and taking into account the existing conditions, the article offers suggestions to optimize the investigation activity with the emphasis on the need for making criminalistic knowledge available to the pre-trial investigation and formation of an "adversarial criminalistics».

Keywords: pre-trial investigation, adversarial criminal trial, establishing the truth, investigation activity, investigation (search) actions, secret investigation (search) actions, criminalistic knowledge, adversarial criminalistics.

УДК 343.98

В. А. Журавель, професор кафедри криміналістики Національного юридичного університету імені Ярослава Мудрого, доктор юридичних наук, членкореспондент НАПрН України

\section{АВТОМАТИЗОВАНІ ІНФОРМАЦІЙНІ СИСТЕМИ ЯК ЗАСІБ ЗАБЕЗПЕЧЕННЯ ЕФЕКТИВНОСТІ ДОСУДОВОГО РОЗСЛІДУВАННЯ}

Розглянуто сучасні інформаційні системи в контексті забезпечення ефективності досудового розслідування, надано їх характеристику, визначено підходи до створення та можливості запровадження в судово-слідчу практику. Показано роль і переваги ичих систем для збільшення якості слідчої діяльності, передусім ї̈ інтелектуальної складової, як-то: висунення й перевірка слідчих версій, планування розслідування, організація розшуку невідомого злочиния тощяо.

Ключові слова: досудове розслідування; інформачійно-довідкова система, інформаційно-пошукова система, інформаційно-модельна система, інформаційно-консультативна система.

(C) Журавель В. А., 2015 
Одним із перспективних напрямів підвищення ефективності організації кримінального провадження слід уважати впровадження в процес досудового розслідування новітніх інформаційних систем і технологій ${ }^{1}$, під якими прийнято розуміти організаційно впорядковану сукупність масивів інформації про об’єкти та інформаційні технології, у тому числі засоби сучасної комп'ютерної техніки, програмне забезпечення й мережі зв'язку, що забезпечують процеси введення, опрацювання та видачі інформаціїㄹ. Стосовно процесу розслідування, то передусім ідеться про розроблення й використання комп'ютерних програм як підгрунтя інформаційного забезпечення підтримки прийняття рішення слідчим, який здійснює розслідування за конкретним кримінальним провадженням, а саме: про забезпечення такої його інтелектуальної діяльності, як планування, і таких його аспектів, як висунення робочих версій та обрання оптимальних систем слідчих (розшукових) і негласних слідчих (розшукових) дій щодо їх перевірення³. Аналогічної думки дотримуються й практичні працівники ${ }^{4}$.

Найбільш продуктивними, такими, що відповідають як сучасному стану наукових досліджень, так і потребам судово-слідчої практики, можна визнати інформаційно-довідкову, інформаційно-пошукову, інформаційно-модельну та інформаційно-консультативну системи ${ }^{5}$. Якщо перші три утворюють-

1 Див.: Белов О. А. Информационное обеспечение раскрытия и расследования преступлений : монография / О. А. Белов. - М. : Юрлитинформ, 2009.

2 Див.: Бірюков B. В. Інформаційно-довідкове забезпечення розслідування злочинів: проблеми теорії та практики : автореф. дис. на здобуття наук. ступеня д-ра юрид. наук : спец. 12.00.09 «Кримінальний процес та криміналістика; судова експертиза; оперативно-розшукова діяльність» / В. В. Бірюков. - К., 2011. - С. 11.

Див.: Журавель B. A. Інформаційне забезпечення підтримки прийняття рішення слідчим / В. А. Журавель // Кримінально-правова охорона життя та здоров'я : матеріали наук.-практ. конф., Харків, 22-23 квітня 2004 р. - К.; Х. : Юрінком Інтер, 2004. - C. 211-214.

4 За підсумками проведеного нами опитування серед найбільш дієвих засобів підвищення ефективності організації розслідування слідчими названі такі: 1) розроблення систем типових версій і механізмів їх використання при розслідуванні конкретного різновиду злочинів, у тому числі із застосуванням комп'ютерної техніки (указало 58 \% опитаних респондентів); 2) удосконалення процедури висунення й перевірення робочих версій і контрверсій $(86 \%)$; 3) більш широка практика застосування алгоритмізації та програмування процедури розслідування (64 \%); 4) розроблення оптимальних систем слідчих дій відповідно до слідчих ситуацій, що виникають $(52 \%) ; 5)$ запровадження тактичних операцій як засобів розв'язання тактичних завдань розслідування (48 \%).

5 Слід зазначити, що в літературі з криміналістики висловлюються й інші точки зору щодо класифікації сучасних інформаційних систем, які використовуються для організації розслідування певної категорії злочинів. Зокрема, В. В. Бірюков у контексті формування власного криміналістичного вчення з умовною назвою «інформаційно-довідкове забезпечення розслідування злочинів» указує, що ефективну роботу з відомостями, які містять інтегровані банки даних, забезпечують інформаційно-пошукові, інформаційно-аналітичні, геоінформаційні та експертні системи (див.: Бірюков В. В. Теоретичні основи інформаційно-довідкового забезпечення розслідування злочинів : монографія / В. В. Бірюков. - Луганськ : РВВ ЛДУВС, 
ся на суто емпіричній основі, то остання базується не тільки на статистично значущій інформації, а й на масиві відповідних знань, насамперед на висновках певної групи експертів, тому їі ще називають експертною системою.

Кожна із зазначених систем має свою історію розвитку, специфіку утворення та сферу застосування ${ }^{1}$. Першими й найбільш поширеними слід уважати інформаційно-довідкову та інформаційно-пошукову системи, призначення яких полягає насамперед у забезпеченні автоматизованого режиму пошуку й оброблення статистичних (кількісних) показників, що відображені в різних видах криміналістичних обліків. Це стосується в першу чергу інформації про осіб, які вчинили злочин, способи вчинення злочину та відповідні сліди, предмети злочинного посягання. При цьому як одиниці обліку можуть виступати місце й час учинення діяння, способи дій, знаряддя й засоби тощо.

Дещо складнішою з точки зору внутрішньої архітектоніки та процесу побудови $є$ інформаційно-модельна система, яка також базується на пошуку й обробленні статистичних (кількісних) показників, але, на відміну від попередніх, кінцевим результатом іiі застосування виступають певні інформаційні моделі. Ці моделі можуть мати ретроспективну або перспективну спрямованість. Перші відтворюють об'єкти пошуку й пізнання, а другі відбивають напрями та характер діяльності самих суб'єктів пізнання. Перші стосуються подій, які відбулися в минулому, другі - що відбудуться в майбутньому.

Стосовно моделей першого рівня, то йдеться про моделювання типових ознак осіб, які вчиняють той чи інший різновид злочинів, тобто про побудову типових версій, наприклад, щодо злочинців, котрі вчиняють умисні вбивства, убивства з ознаками психосексуальних аномалій, квартирні крадіжки в умовах великих промислових міст тощо. Такого роду моделювання здійснюється на підставі виявлення кореляційних залежностей між елементами криміналістичної характеристики певної категорії злочинів (за рахунок зіставлення вихідних даних із комплексами ознак, що притаманні особам, які вчиняють ці злочини). У свою чергу моделі перспективної спрямованості відтворюють припущення стосовно можливої нової жертви злочинного по-

2009. - С. 266-309). У свою чергу К. І. Бєляков виділяє інформаційно-логічні (АІЛС) та інформаційно-пошукові (АІПС) системи. На думку автора, системи штучного інтелекту АІЛС являють собою засоби, що поряд із масивами даних стосовно певних об'єктів мають базу знань 3 певної галузі, на яку вони орієнтовані, нею вони оперують у процесі опрацювання інформації. Такі інформаційні системи за відповідними алгоритмами опрацьовують необхідну інформацію й за результатами дають виважені рекомендації щодо певної діяльності. Опрацьовуючи інформацію, вони здатні «генерувати» рекомендації, логічні висновки i, як мінімум, надавати нову інформацію (див.: Беляков К. И. Совершенствование информационного обеспечения расследования преступлений на базе АИЛС : автореф. дис. на соискание уч. степени канд. юрид. наук : спец. 12.00.09 «Уголовный процесс и криминалистика; судебная экспертиза» / К. И. Беляков. - К., 1993. - С. 11-12).

1 Див.: Полевой Н. С. Криминалистическая кибернетика / Н. С. Полевой. - М. : Изд-во МГУ, 1982. 
сягання, можливого місця й часу вчинення нового злочину, що готується, найбільш імовірного суб'єкта та імовірних місць його резиденції.

Сучасний стан комп'ютерних розробок дозволяє виявити кореляційні залежності між елементами криміналістичної характеристики певної категорії злочинів не наочним шляхом, як це здійснювалось раніше, а із застосуванням математичної обробки репрезентативної вибірки кримінальних проваджень. Саме комп'ютерні програми автоматизованої обробки емпіричних даних дозволяють установити найбільшу кількість кореляційних залежностей між елементами криміналістичної характеристики розглядуваної категорії злочинів, перенести отримані дані в кореляційні таблиці, а в подальшому на їх підставі побудувати систему типових версій щодо особи злочинця, мотиву та способу вчинення злочину. При цьому опрацювання даних, відображених у кореляційних таблицях, також має здійснюватися комп'ютерними засобами, з тим щоб максимально сприяти нівелюванню взаємовпливу різноманітних перемінних і хитких даних, що можуть впливати на перекручення тенденцій.

Інформаційно-модельна система також передбачає створення спеціальної комп'ютерної програми, яка дозволяє здійснювати математичні розрахунки ймовірних місць резиденції злочинців і можливих місць учинення ними нових злочинів. Ідеться насамперед про серійні вбивства, яким притаманні певні закономірності щодо жертви, способу, обставин злочину, особи злочинця. Саме наявність цих закономірностей, їх константність, 3 одного боку, підкреслює серійний характер учинених убивств, а з другого слугує підставою для розроблення цієї програми.

В основу побудови зазначеної програми може бути покладена інформація щодо таких параметрів, як вік злочинця, час і місце вчинення злочину, жертва злочину, причому таким чином, щоб з обмеженої кількості зібраних відомостей про минуле ймовірного злочинця та його поведінку за допомогою цієї програми можна було визначити регіон і місце розташування оселі злочинця, звідки він виходить на свої операції. Програма може працювати на підставі звірених даних про можливого злочинця та обставин учинених ним злочинів із так званими «ресурсними характеристиками», тобто з ознаками всіх ідентичних злочинів, інформацією про злочинців, яка міститься в базі даних комп'ютера.

Формування бази даних розглядуваної комп’ютерної програми доцільно здійснювати з урахуванням певних рекомендацій щодо найбільш ефективних процедур визначення й розрахунків географічно орієнтованих відомостей про вчинені злочини. Насамперед при використанні координатної інформації про місця вчинення злочинів необхідно вивести географічне уявлення про місця всіх узятих на облік злочинів цієї категорії, у яких повинні бути відображені пов' язані зі злочинами відповідні географічно орієнтовані дані щодо оселі злочинця, тобто проаналізувати кожен злочин із погляду розташування оселі злочинця й місця вчинення злочину. Слід також виходити 3 того, що в загальному плані всі злочинці поділяються на категорії залежно від можливостей і ресурсів: часу, наявності автомобіля, витрат на проїзд, 
знання району злочину, усіх його особливостей. За таких умов до банку даних можуть бути внесені відомості про:

- місце вчинення злочину (приміщення, відкрита місцевість) і райони проживання злочинця;

— час учинення злочину (дні тижня) і відстань, яку проїжджає злочинець до місця вчинення кримінального акту;

— вік злочинця;

— особу жертви злочину та ії взаємовідносини зі злочинцем.

При цьому якщо в ході оброблення зазначених відомостей засобами комп'ютерної техніки виявляється, що місця злочинів уключають і місце проживання злочинця, то перевагу слід віддавати моделі «місцевого» злочинця. А якщо район розташування оселі лежить за межами району вчинення злочинів, тоді більше підходить модель «приїжджого» злочинця. Крім того, необхідно пов'язувати місце проживання злочинця з місцем учинення ним першого злочину, оскільки саме максимальна і мінімальна дистанції від оселі до місця першого злочину, виявленого в обраній групі злочинців, можуть використовуватися як радіуси двох кіл, центри яких були місцями першого злочину, учиненого конкретним злочинцем. Простір між цими двома колами тоді й буде найбільш імовірним місцем розташування оселі цього нового злочинця, тобто саме там його слід шукати ${ }^{1}$.

У криміналістиці поряд із засобами, що базуються на статистичному аналізі інформації стосовно розслідування, поступово отримують розвиток і практику застосування інформаційні системи, які засновані на збиранні, класифікації та використанні узагальненого досвіду розслідування у вигляді суджень певної категорії досвідчених фахівців. Такого роду знання, що зафіксовані спрощено в правилі - «якщо є такий-то факт, то, імовірно, мала місце така-то дія й учинена вона з таким-то мотивом» і підготовлені для оброблення на комп'ютерній техніці, дозволяють прийнятно імітувати процес оцінювання слідчим ситуації розслідування й забезпечити в режимі діалогу консультаційну підтримку прийняття ним відповідного рішення 2 . Справа в тому, що навіть досконало розроблені та апробовані криміналіс-

1 Див.: Журавель В. А. Криміналістичні прогнози як засіб протидії серійним вбивствам / В. А. Журавель, В. Л. Синчук // Вісн. Луган. акад. внутр. справ України. — Луганськ : РВВ ЛАВС, 2002. — Вип. 3. - С. 183-188.

2 Новим кроком до впровадження ідей «штучного інтелекту» в слідчу практику можна вважати створення комп'ютерних інформаційно-консультативних систем як прообразів автоматизованих методик розслідування, формування яких вважається вельми перспективним і актуальним (див.: Кушниренко С. П. Криминалистическая характеристика и типовые программы расследования хищений чужого имущества путем мошенничества с использованием лжепредприятий : автореф. дис. на соискание уч. степени канд. юрид. наук : спец. 12.00 .09 «Уголовный процесс; криминалистика; теория оперативно-розыскной деятельности» / С. П. Кушниренко. - СПб., 1996. - С. 19; Тишутина И. В. Первоначальный этап раскрытия и расследования бандитизма : автореф. дис. на соискание уч. степени канд. юрид. наук : спец. 12.00.09 «Уголовный процесс; криминалистика и судебная экспертиза; оперативно-розыскная деятельность» / И. В. Тишутина. - М., 2003. — С. 12 та ін.). 
тичні рекомендації виявляються занадто складними для безпосереднього їх використання в ході розслідування конкретного злочину не тільки для початківців, а й для досвідчених слідчих. Ось чому одне 3 найбільш важливих завдань при цьому полягає в правильному виділенні та описанні ознак вихідної ситуації, їх співвідношення з предметом доказування, а також установлення відповідних логічних взаємозв’язків.

Допомогти слідчому вирішити зазначені завдання саме й призначені інформаційно-консультативні системи. Саме вони на підставі усвідомлення та аналізування вихідної інформації, формування слідчих версій сприяють визначенню оптимальної послідовності проведення окремих слідчих (розшукових) і негласних слідчих (розшукових) дій. При цьому йдеться не лише про визначення стратегічних напрямів розслідування, а й про обрання тактики (технологіiі) проведення окремих слідчих (розшукових) дій. Зокрема, слідчий може скористатися так званими демонстраційними прикладами, скажімо, отримати перелік можливих експертиз, які призначаються при розслідуванні певного виду (різновиду) злочинів, і вирішуваних питань, або перелік можливих ситуацій, які складаються на певному етапі розслідування, та можливих алгоритмів дій слідчого щодо виходу із цих ситуацій тощо.

Водночас інформаційно-консультативні системи сприяють поповненню відсутніх досвіду та знань у слідчих і співробітників оперативних підрозділів, оскільки менш досвідчені працівники отримують можливість нарівні 3 професіоналами, тобто тими, що мають значний досвід роботи з аналогічних кримінальних проваджень, однаково чітко підходити до оцінювання вихідної інформації, здійснювати побудову слідчих версій, обирати найбільш раціональну послідовність проведення слідчих (розшукових) і негласних слідчих (розшукових) дій як засобів впливу на слідчі ситуації, що складаються ${ }^{1}$.

Виходячи 3 того, що розслідування - це завжди складний пізнавальний процес, реалізація якого здійснюється головним чином евристичним (творчим) шляхом, де алгоритмічний виконує лише допоміжну роль, то й програмування слід розглядати як складову частину, певний етап планування. Слідчий, спираючись на розроблені наукові програми дій відповідно до ситуації, що виникла, і враховуючи реальні можливості, складає детальний план розслідування. За таких обставин значення програмування як засобу доведення методичних рекомендацій до слідчого полягає в тому, що воно надає йому можливості в тих випадках, коли є готові оптимальні рішення, не займатися їх винаходом, а брати й використовувати вже готові ${ }^{2}$. При цьому обов'язково слід ураховувати, що методичні приписи, які містяться в програмі, це лише передумови до діяльності, у той самий час успіх розслідування досягається не стільки ступенем їх опанування, скільки професійним

1 Див.: Журавель В. А. Інформаційне забезпечення процесу розслідування: шляхи та засоби / В. А. Журавель // Вісн. Акад. прав. наук України. - Х. : Право, 2004. - Вип. 2(37). - С. 175-180.

2 Див.: Соя-Серко Л. А. Программирование и творчество в деятельности следователя / Л. А. Соя-Серко // Проблемы предварительного следствия в уголовном судопроизводстве : сб. науч. тр. - М. : ВИИПРМПП, 1980.- С. 33. 
використанням в умовах конкретної ситуації. Оскільки це так, то застосування алгоритмічних схем, програм вимагають від слідчого значних інтелектуальних зусиль. Ідея алгоритмізації та програмування розслідування не повинна позбавляти слідчого можливості пошуку евристичних рішень, навпаки, програма повинна стимулювати його ініціативу щодо відшукання нового оригінального рішення, навіть такого, яке не передбачене їі розробниками ${ }^{1}$. У зв'язку 3 цим програми розслідування мають бути побудовані так, щоб слідчий міг на їх основі висувати версії по справі, що розслідується, і планувати провадження окремих слідчих дій, використовуючи при цьому власний практичний досвід, свої інтелектуальні можливості, спираючись на інтуїцію та евристичні рішення ${ }^{2}$.

При цьому необхідно визнати, що на сьогодні далеко не всі практики чітко розуміють перевагу такої форми викладення методичних порад, із настороженістю ставляться до них, побоюючись шаблонності й зниження творчого потенціалу. Про це свідчать результати опитування як початківців, так і досвідчених слідчих. Так, 36 \% 3 опитаних нами слідчих не вважають більш широку практику застосування алгоритмізації та програмування дієвим засобом підвищення ефективності організації й планування процесу досудового розслідування. Такого роду сумніви з боку практичних працівників необхідно розвіювати саме науковцям, насамперед за рахунок здійснення типізації слідчих ситуацій відповідно до різних категорій злочинних проявів і етапів їх розслідування (вихідного, початкового, наступного), визначення до кожного з них вичерпного переліку стратегічних і тактичних завдань, розроблення й запровадження оптимальних програм розслідування та алгоритмічних схем дій слідчого щодо їх розв’язання.

Отже, криміналістичні алгоритми й програми розслідування мають бути розроблені в такий спосіб, щоб вони стимулювали ділову активність слідчого, істотно полегшували його розумову діяльність, забезпечували швидкість прийняття ним рішень з урахуванням усіх без винятку рекомендацій криміналістики та вимог чинного законодавства. Разом із тим вони в жодному разі не повинні заміняти індивідуальність, професіоналізм, стиль мислення слідчого, не позбавляти його творчих засад, тим більше, що при всьому бажанні нестандартне рішення в розслідуванні злочинів запрограмувати неможливо. «Як би не розвивалося програмування розслідування, наголошував I. С. Биховський, - воно не повинно переслідувати мету створення слідчого-робота замість слідчого-дослідника»³. Т. С. Волчецька також підкреслює, що типову програму слідчий має застосовувати не автоматично,

1 Див.: Быховский И. Е. Программирование расследования: возможности и перспективы / И. Е. Быховский // Актуальные проблемы советской криминалистики : сб. науч. тр. - М. : ВИИПРМПП, 1980. - С. 66-67.

2 Див.: Гуняев В. В защиту криминалистических программ / В. Гуняев, С. Кузьмин // Соц. законность. - 1990. - № 3. - С. 49.

3 Быховский И. Е. Типовые версии и программирование расследования: возможности и перспективы / И. Е. Быховский // Актуальные проблемы советской криминалистики (материалы для обсуждения на расшир. заседании уч. совета). М. : ВИИПРМПП, 1979. - С. 58. 
суворо дотримуючись усіх їі пунктів, а творчо, пристосовуючи іiі до конкретного процесу розслідування ${ }^{1}$. Ще більш категоричною у своїх судженнях $\epsilon$ Т. О. Сєдова, яка наголошує, що використання типових програм не перешкоджає, а, навпаки, створює більший простір для творчого процесу, тому що звільняє розумову діяльність слідчого від рутинного, типового, повсякденного ${ }^{2}$. При цьому самі алгоритми й програми виступають своєрідним способом концентрації криміналістичних знань, акумулятором узагальненого досвіду слідчої діяльності, підвищують їі ефективність, перетворюючи на програмно керовану та більш контрольовану при розв’язанні однотипних завдань розслідування, створюючи відповідні умови для економії інтелектуальної праці слідчого, її автоматизації там, де це можливо й необхідно.

Принципи та ідеї алгоритмізації й програмування набувають особливого значення ще й тому, що виникає об'єктивна можливість їх реалізації засобами комп'ютерної техніки, оскільки на сьогодні кожний слідчий має в користуванні персональний комп'ютер. Зазначене зумовлює ще один напрям спільних досліджень криміналістів і математиків-програмістів стосовно формалізації існуючих та створення нових алгоритмів і програм розслідування, які б мали вигляд довідково-консультаційного посібника для слідчих. Звернення до цих джерел і могло б стати тим необхідним засобом оперативного одержання управляючої інформації, який реально сприятиме підвищенню рівня ефективності пізнавальної, конструктивної та організаційної діяльностей слідчого.

\title{
АВТОМАТИЗИРОВАННЫЕ ИНФОРМАЦИОННЫЕ СИСТЕМЫ КАК СРЕДСТВО ОБЕСПЕЧЕНИЯ ЭФФЕКТИВНОСТИ ДОСУДЕБНОГО РАССЛЕДОВАНИЯ
}

\author{
Журавель В. А.
}

Рассмотрены современные информационные системы в контексте обеспечения эффективности досудебного расследования, предоставлена их характеристика, определены подходы к созданию и возможности внедрения в судебно-следственную практику. Показань роль и преимущества этих систем для повышения качества следственной деятельности, прежде всего ее интеллектуальной составляющей, а именно для выдвижения и проверки следственных версий, планирования расследования, организации розыска неизвестного преступника.

Ключевые слова: досудебное расследование; информационно-справочная система, информационно-поисковая система, информационно-модельная система, информационно-консультационная система.

1 Див.: Волчеикая Т. С. Современные проблемы моделирования в криминалистике и следственной практике: учеб. пособие / Т. С. Волчецкая. - Калининград : Изд-во Калининград. ун-та, 1997. — С. 46.

2 Див.: Седова T. A. Проблемы алгоритмизации оценочной деятельности следователя / Т. А. Седова // Проблемы прогнозирования, организации и информационного обеспечения предварительного следствия : межвуз. науч. сб. - Уфа : Изд-во Башкир. ун-та, 1989. - С. 61. 


\section{AUTOMATED INFORMATION SYSTEMS AS A MEANS FOR ENSURING THE PRE-TRIAL INVESTIGATION EFFICIECY}

\section{Zhuravel $V . A$.}

The article deals with modern information systems with regard to ensuring the pre-trial investigation efficiency. It underscores that information reference, information search, information modelling and information consulting systems must be regarded as the most efficient systems that meet the up-to-date requirements of scientific research and satisfy the needs of forensic and investigation practices. The first three systems are based on empirical data while the fourth one is based not only on the statistically significant information, it also encompasses an array of necessary knowledge including conclusions of a certain group of experts, hence this system is often regarded as an expert system. The abovementioned information systems are designed to provide support in the decision-making by investigators while dealing with specific crimes, they contribute to the investigators 'mental activity in planning, suggesting investigation versions, choosing optimal systems for investigation (search) actions. These information systems can be launched following the development and introduction of necessary software, the use of personal computers available to any investigator in order to obtain necessary data or examples (the system of operational versions, model questionnary for a forensic expert, etc).

Keywords: pre-trial investigation, information reference system, information search system, information modelling system, information consulting system.

УДК 343.9(075.8)

B. H. Tерехович, адвокат Коллегии присяжных адвокатов Латвии, доктор права, доцент,

Э. В. Ниманде, доцент кафедры уголовно-правовых наук Латвийского университета, доктор права, доцент

\section{СЕМИОТИЧЕСКИЕ СРЕДСТВА КРИМИНАЛИСТИЧЕСКОГО ПОЗНАНИЯ}

С позищии современных основ семиотики и практики расследования преступных деяний описаны особенности знаковой системы средств криминалистического познания. Раскрыта сущность символических, индексных и изобразительных средств познания, которые используются в процессе расследования преступных деяний.

Ключевые слова: семиотика, уголовное правоприменение, теория криминалистики, расследование преступных деяний, средства криминалистического познания.

Уголовное правоприменение является социально положительной функцией государства. Для процесса уголовного правоприменения характерна (C) Терехович В. Н., Ниманде Э. В., 2015 